\title{
Dynamic correlation of apoptosis and immune activation during treatment of HIV infection
}

\author{
Andrew D. Badley ${ }^{\star 1,2,3}$, Karl Parato ${ }^{2,3}$, \\ D. William Cameron ${ }^{1,2,3}$, Stephen Kravcik', \\ Barbara N. Phenix ${ }^{2,3}$, Deborah Ashby ${ }^{2,3}$, Ashok Kumar ${ }^{3}$, \\ David H. Lynch ${ }^{4}$, Jurg Tschopp ${ }^{5}$ and Jonathan B. Angel ${ }^{1,2,3}$ \\ 1 Division of Infectious Diseases, Department of Medicine, Ottawa General \\ Hospital, Canada \\ 2 Ottawa General Hospital Research Institute, Canada \\ ${ }^{3}$ Department of Biochemistry, Microbiology and Immunology, University of \\ Ottawa, Canada \\ ${ }^{4}$ Immunex Corporation, Seattle, Washington, USA \\ ${ }^{5}$ Universite De Lausanne, Switzerland \\ * corresponding author: Andrew Badley, Division of Infectious Diseases, Ottawa \\ General Hospital, 501 Smyth Road, Room G12, Ottawa, Ontario K1H 8L6, \\ Canada. tel: (613) 737-8998; fax: (613) 737-8682 \\ e-mail: < abadley@ogh.on.ca>
}

Received 28.9.98; revised 8.12.98; accepted 4.2.99

Edited by M.L. Gougeon

\section{Abstract}

T cells from HIV infected patients undergo spontaneous apoptosis at a faster rate than those from uninfected patients, are abnormally susceptible to activation induced cell death (AICD), and undergo increased apoptosis in response to Fas receptor ligation. These observations have led to the hypothesis CD4 T cell apoptosis may be a mechanism of CD4 T cell depletion and the pathogenesis of AIDS. Successful treatment of HIV infected patients is accompanied by quantitative and qualitative improvements in immune function reflecting at least partial reversibility of the underlying pathogenesis of HIV. In this report we correlate improvements in markers of immune function with a decrease in apoptosis, and changes in its regulation. Therapy with nelfinavir plus saquinavir in combination with two nucleoside analogue inhibitors of reverse transcriptase dramatically reduces plasma viremia and increases CD4 T cell counts. Coincident with these improvements, CD38 and HLA-DR coexpression on both CD4 and CD8 T cells decrease, and CD45RA and CD62L coexpression increase. Furthermore, spontaneous apoptosis decreases in both CD4 and CD8 T cells (CD4 apoptosis 17.4 vs $2.6 \%, P=0.005$; CD8 apoptosis 15.0 vs $1.0 \%, P<0.001)$, as does both Fas mediated apoptosis (CD4 apoptosis 19.0 vs $3.5 \%$, $P=0.03$; CD8 apoptosis 13.7 vs $1.5 \%, P=0.002)$ and CD3 induced AICD (CD4 apoptosis 13.7 vs 3.2\%, $P=0.001$; CD8 apoptosis 29 vs 2.2\%, $P=0.08$ ). Changes in apoptosis are not associated with changes in Fas receptor expression, but are significantly correlated with changes in activation marker profiles. Although this suggests a possible regulatory role for the apoptosis inhibitory protein FLIP, direct assessment did not reveal quantitative differences in FLIP expression between apoptosis resistant PBL's from HIV negative patients, and apoptosis sensitive PBL's from HIV positive patients. These findings support the hypothesis that apoptosis mediates HIV induced CD4 T cell depletion, but indicate the need for further studies into the molecular regulation of HIV induced apoptosis.

Keywords: HIV; apoptosis; AICD; Fas; FLIP; activation

Abbreviations: AICD, activation induced cell death; AIDS, acquired immunodeficiency syndrome; AZT, azithothymidine; BSA, bovine serum albumin; CTL, cytotoxic T lymphocytes, DDC, 2', 3'-dideoxycytidine; ECL, electrochemoluminescence; FITC, fluorescein isothyocyanate; FLICE, FADD like ICE (Caspase 8); FLIP, FLICE inhibitory protein; HIV, human immunodeficiency virus; $\mathrm{MHC}$, major histocompatibility complex; NS, non significant; PBL, peripheral blood lymphocytes; PBMC's, peripheral blood mononuclear cells; PBS, phosphate buffered saline; TCR, T cell receptor; TNF, tumor necrosis factor; TRAIL, TNF related apoptosis inducing ligand

\section{Introduction}

Recent advances in the understanding of the pathogenesis of human immunodeficiency virus (HIV) infection have led to treatments that restore CD4 $\mathrm{T}$ cell counts and improve immune function of HIV infected individuals. ${ }^{1-9}$ One approach to therapy has been combinations of HIV protease inhibitors ${ }^{10}$ and nucleoside inhibitors of HIV reverse transcriptase, which together result in partial immune reconstitution of some patients. ${ }^{1}$ The effectiveness of these treatments suggests that the pathogenic mechanism(s) responsible for the induction of CD4 T cell loss in untreated patients are reversed by such therapies.

Although considerable controversy exists, apoptosis is emerging as the most plausible mechanism responsible for CD4 $T$ cell depletion in patients infected with HIV. ${ }^{11-13}$ Apoptosis is a tightly regulated process of cellular death that may be induced by both death receptor initiated signalling, ${ }^{14}$ or by mechanisms which bypass the requirement for receptor ligation. ${ }^{15} \mathrm{~T}$ cells from HIV infected persons when cultured ex vivo demonstrate enhanced apoptosis in the absence of stimuli (spontaneous apoptosis) in comparison with cells from HIV negative patients. ${ }^{16,17}$ Increased spontaneous apoptosis has consistently been observed to correlate directly with the rate of disease progression: rapid progressors have the highest rates of spontaneous apoptosis, ${ }^{18-20}$ whereas long term non progressors have rates of apoptosis similar to HIV negative subjects. ${ }^{18,21,22}$ In addition to enhanced spontaneous apoptosis, peripheral blood mononuclear cells from HIV 
infected patients and HIV infected monocyte derived macrophages develop the ability to induce apoptosis of autologous CD4 and CD8 T cells. ${ }^{23-30}$ This phenomenon, in addition to enhanced susceptibility of $\mathrm{T}$ cells from HIV infected patients to undergo Fas mediated apoptosis, ${ }^{31-36}$ suggest that the Fas/Fas Ligand (FasL) system is involved in HIV induced apoptosis. Indeed, interruption of Fas/FasL interaction abrogates the ability of macrophages to induce autologous cell killing. ${ }^{23,24,26,28}$ Recent demonstration of increased $\mathrm{T}$ lymphocyte apoptosis in lymphoid tissues of HIV infected patients, ${ }^{37-41}$ elevated macrophage associated FasL within the lymphatic tissues of infected patients ${ }^{40,41}$ and the correlation of FasL with the presence of increased $T$ lymphocyte apoptosis ${ }^{41}$ lends support to the importance of Fas mediated $T$ cell death in vivo. A third mechanism of $\mathrm{T}$ cell apoptosis in
HIV infected patients is related to the profound immune activation which occurs in HIV infected patients. ${ }^{42,43}$ $\mathrm{T}$ cell activation leads to a state of enhanced susceptibility to apoptotic cell death. When activated cells then encounter another activating stimulus, de novo production of FasL results in apoptosis. ${ }^{44,45}$ Experimental systems which study this activation induced cell death (AICD), use mitogens or $\mathrm{T}$ cell receptor (TCR) ligation as an activation stimulus to induce AICD. In this regard, $T$ cells from HIV infected patients are more prone to AICD than those from HIV negative patients, ${ }^{46-48}$ possibly due to activation induced by viral gp $120 .^{26,49}$

Since apoptosis is one potential pathogenic mechanism responsible for HIV mediated $\mathrm{T}$ cell death and CD4 $\mathrm{T}$ cell depletion in AIDS, we have evaluated the amount of apoptosis that occurs before and after the initiation of

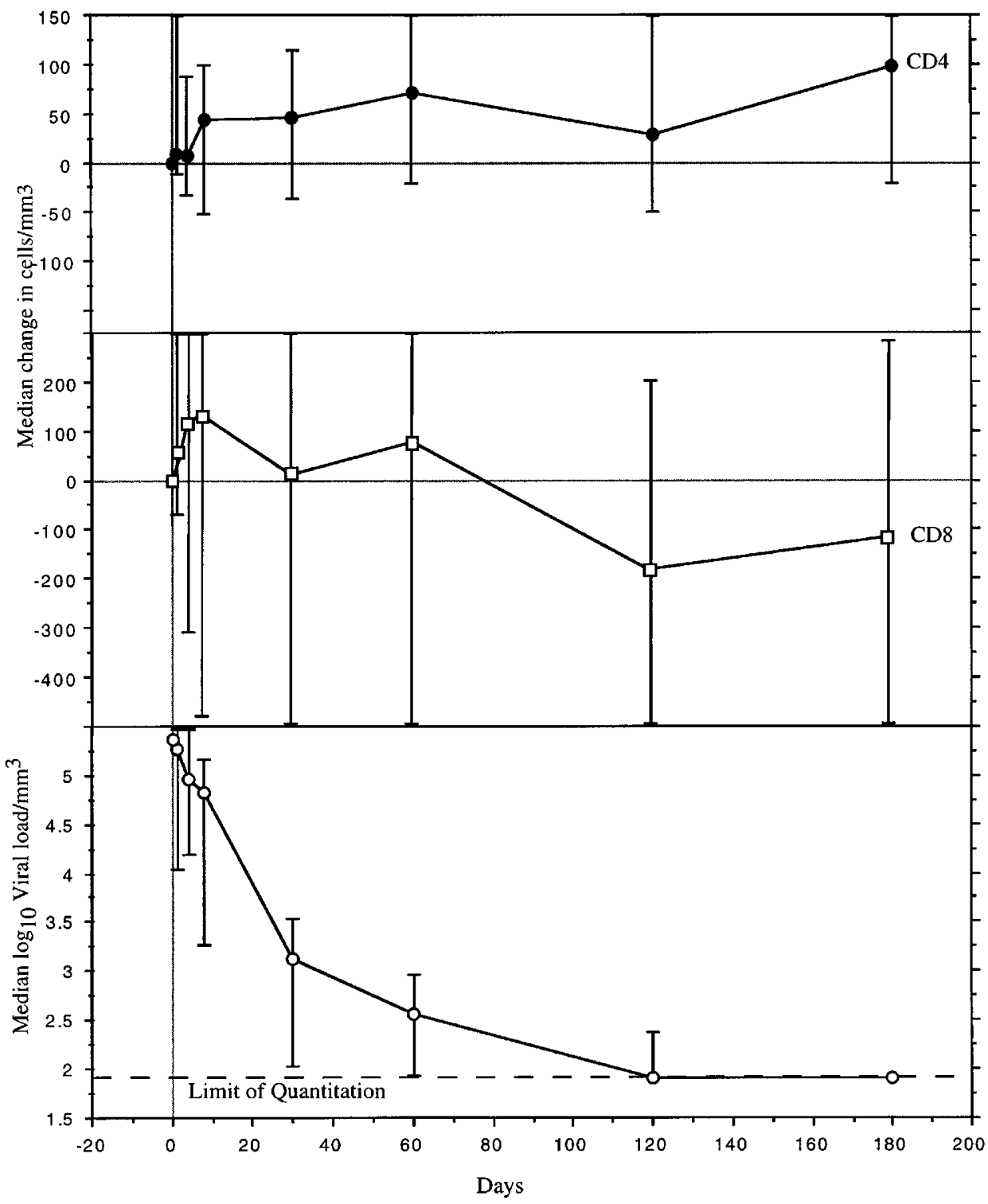

Figure 1 Virologic and T cell response to therapy. CD4 and CD8 T cell counts and plasma HIV viral RNA levels were determined prior to and during therapy with nelfinavir, saquinavir and two nucleoside analogue inhibitors of HIV reverse transcriptase. (Bars represent 25th and 75th percentiles) 
potent antiretroviral therapy. Infected patients that were not previously treated with protease inhibitors were enrolled in a pharmacokinetic and anti-HIV activity trial of nelfinavir and saquinavir in combination with two nucleoside analogue inhibitors of HIV reverse transcriptase. Blood samples were analyzed before and during therapy for enumeration of $T$ cell subsets, quantitation of plasma HIV viral load, measurement of markers of immune function, and for apoptosis markers.

\section{Results}

\section{Virologic and $\mathrm{T}$ cell response to therapy}

Ten patients were enrolled and followed for 6 months. One patient discontinued treatment after 4 weeks for reasons unrelated to study medications. In the remaining patients, pretreatment median plasma viremia was $5.3 \log _{10}$ copies $/ \mathrm{ml}$ (range 3.61 - $6.38 \log _{10}$ HIV RNA genomes/ml), median CD4 count was 301 cells $/ \mu$ l (range $21-114$ cells $/ \mu \mathrm{l}$ ) and median CD8 T cell count was 1162 cells $/ \mu$ l (range $575-1567$ cells $/ \mu l$ ). A rapid decline in plasma viremia was observed following the initiation of treatment with a median $2.23 \log _{10}$ reduction from baseline observed by day 30 (Figure 1). Following 120 days of treatment, median viral load was below the lower limit of quantitation of 80 copies (seven to nine patients below detection). By day 180, eight to nine evaluable patients had plasma viremia below 80 copies $/ \mathrm{ml}$ (overall $P=0.05$ ). Sustained increases from baseline in CD4 T cell counts were observed, with a 47 cell $\mu \mathrm{l} /$ median increase (range
-185 to +342 cells; $P=N S$ ) occurring after 8 days of treatment; following 180 days of treatment, the median CD4 $\mathrm{T}$ cell count had risen by $97 \mathrm{cell} / \mu \mathrm{l}$ (range -77 to +183 cells; day 0 vs day $180 P=0.05)$. Similar to previous observations in patients treated with protease inhibitor based antiretroviral therapy, ${ }^{7}$ the CD8 T cell response to therapy was biphasic, within an initial increase in CD8 T cell counts being followed by a decline. By day 8 after therapy, the median CD8 T cell count had increased by 134 cells $/ \mu$ l (range -518 to +744 cells $\mathrm{P}=\mathrm{NS}$ ). After 180 days the median CD8 T cell count had fallen by 126 cells $/ \mu$ l (range -724 to +579 cells $P=N S$ ).

\section{Immune reconstitution following therapy}

Considerable recent attention has been focused on immune reconstitution following effective anti-retroviral therapy. These studies have demonstrated that suppressed viral replication is followed by decreased immune activation, increased expression of co-stimulatory molecules, and increased numbers of naive circulating $T$ cells. ${ }^{1-9}$ Other studies indicate that abnormal $\mathrm{T}$ cell activation occurs in HIV infection, $2,43,50,51$ and that this abnormality increases susceptibility of $T$ cells to become infected, ${ }^{52-54}$ or to die by apoptosis. ${ }^{35,55,56}$ The abnormal state of activation may therefore be central to the pathogenesis of HIV disease. Consequently, we analyzed the activation profile of CD4 and CD8 T cells before and during therapy. Co-expression of CD38 and HLA-DR were analyzed in CD4 and CD8 T lymphocytes at day zero, 60, and 180 (Figure 2). Despite rising CD4 T cell counts, the median number of CD4 $T$ cells expressing CD38 and HLA-DR
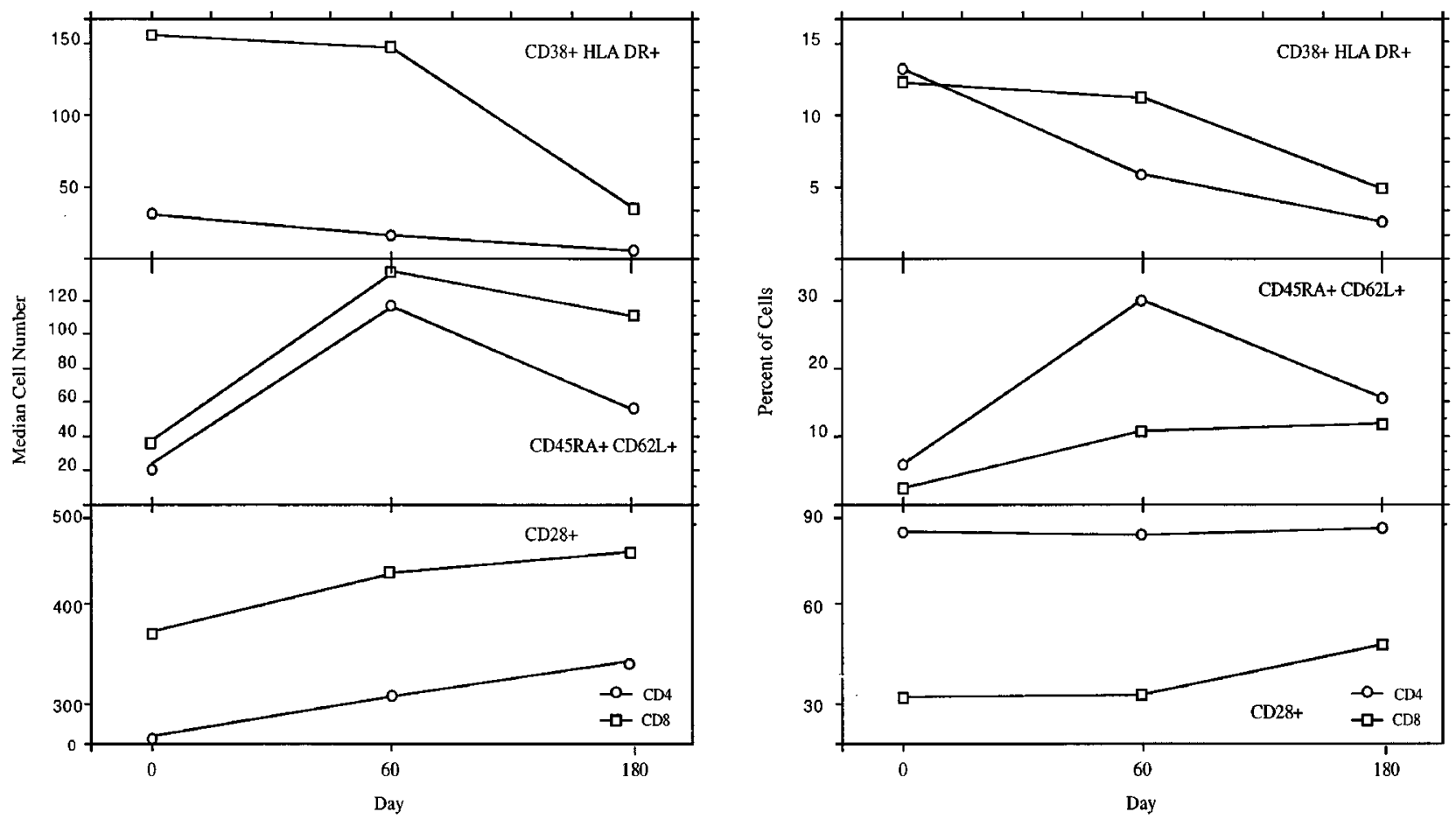

Figure 2 Immunophenotype subset analysis. Prior to and during antiretroviral therapy, the absolute number of CD4 (O) and CD8 ( $\square)$ T cells which co-expressed CD38 and HLADR (top panels) CD45RA and CD62L (middle panels) or CD28 (lower panels) were analyzed by flow cytometry. Data is expressed either as median cell number (left panels) or as percentage of CD4 or CD8 T cells (right panels) 
decreased from a pre treatment level of $30.5 / \mu$ l cells (range $5-163$, standard error $=14.7$ ) to $24 \mathrm{cells} / \mu$ l (range $3-40$, standard error 4.8 ) by day 60 , and to $5.5 \mathrm{cells} / \mu$ l (range $1-30$, standard error 3.5) by day 180 (overall $P=0.04$ ). A reduction in activation profile was also observed in CD8 T cells, with the mean baseline number of CD8 T cells expressing CD38 and HLA-DR of 161 cells/ $\mu$ l (range 20-566, standard error 59.6) decreasing to $155.5 \mathrm{cells} / \mu \mathrm{l}$ (range 53-244, standard error $=26.1$ ) by day 60 and to $40.0 \mathrm{cells} / \mu \mathrm{l}$ (range $30-85$, standard error $=9.7$ ) by day 180 (overall $P=0.005$ ).

We next analyzed the number of naive CD4 and CD8 T cells before and during therapy. Co-expression of CD45RA and $C D 62 L$ was used to identify the naive $T$ cell subsets. ${ }^{6,57}$ At baseline, the median number of CD45RA and CD62L positive (naive) CD4 T cells was 19.5 cells $/ \mu$ l (range 2-392, standard error 37.4), which increased to 114 (range 5-346, standard error 35.3) at day 60 (overall $P=0.02$ ). At day 180 , median 58.5 (range 13-113, standard error $=11.9$ ) naive CD4 $\mathrm{T}$ cells $/ \mu \mathrm{l}$ were present. This was less on day 60 , but still greater than baseline (overall $P=0.03$, Figure 2). The median number of naive CD45RA and CD62L positive CD8 T cells also exhibited an initial increase from 37.5 cells $/ \mu$ l (range 10-319, standard error 37.7 ) to $134 \mathrm{cells} / \mu \mathrm{l}$ (range 22-452, standard error=49.9) 60 days after starting treatment (overall $P=0.03$ ). At 180 days post treatment, the number of naive cells decreased to $114.5 / \mu \mathrm{l}$ (range $34-287$, standard error=33.7), but this was still significantly greater than at baseline (day 0 vs day $180 P=0.04$ ).

Having demonstrated a decrease in activation markers and an increase in naive CD4 and CD8 T cells, we next assessed CD28 as a surrogate marker of immune function. Optimal $\mathrm{T}$ cell function requires the interaction of $\mathrm{T}$ cells with antigen presenting cells. This interaction occurs primarily through the $\mathrm{T}$ cell receptor (TCR) and $\mathrm{MHC}$ class II molecules, and is further enhanced by the costimulatory molecule B7 (expressed by antigen presenting cells) and CD2858,59 (expressed by $\mathrm{T}$ cells). Previous reports in patients with HIV infection have demonstrated a decrease in CD28 expression on CD8 T cells and to a lesser extent, on CD4 $\mathrm{T}$ cells. ${ }^{60,61}$ Indeed, defects in proliferative function of CD4 $\mathrm{T}$ cells from HIV positive patients may be due to a decrease in CD28 expression. ${ }^{62}$ We therefore analyzed the number of cells expressing

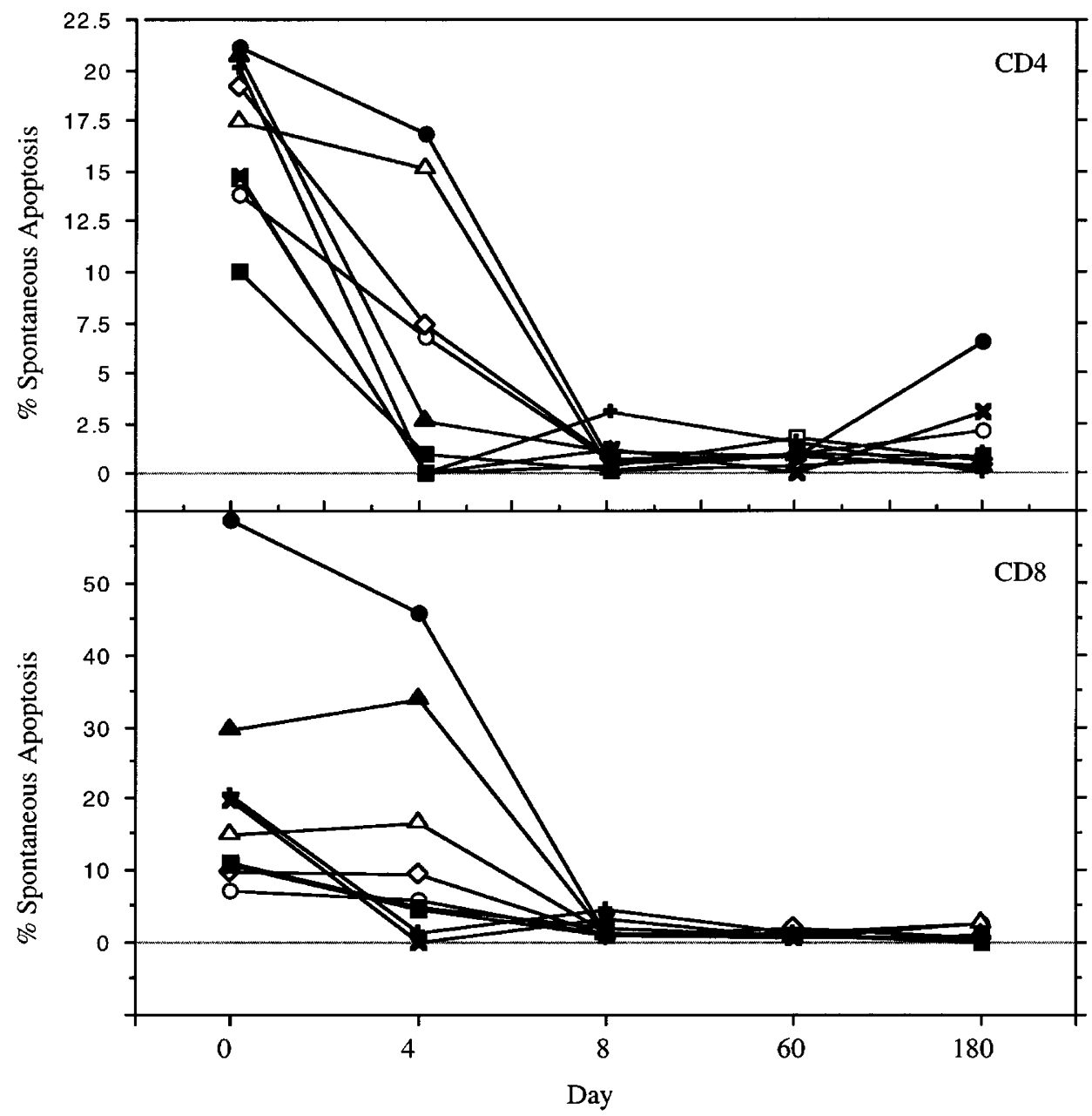

Figure 3 Analysis of spontaneous apoptosis. Prior to and during antiretroviral therapy, the number of CD4 (top panel) and CD8 T cells (bottom panel) undergoing spontaneous apoptosis was determined using annexin $\mathrm{V}$ and analyzed by multiparameter flow cytometry 
CD28 before and following treatment. The median number of CD4 T lymphocytes expressing CD28 rose from 253 cells $\mu \mathrm{l}$ (range $3-993$, standard error 89.7) to 306 (range $27-625$, standard error 69.6) by day 60 and was 323 cells/ $\mu \mathrm{l}$ (range 70-1134, standard error 118.4) at 180 days (overall $\mathrm{P}=\mathrm{NS}$, Figure 2). CD8 $\mathrm{T}$ cell expression of CD28 also increased from 381.5 cells/ $\mu$ l (range 10-972, standard error 90.7$)$ to 404 (310-957, standard error 72.9) by day 60 , and to 445 (range 257-579, standard error 43.6) after 180 days of treatment, although differences did not reach significance.

\section{Analysis of apoptosis following treatment}

Of the candidate mechanisms responsible for the induction of CD4 T cell death, aberrant apoptosis has consistently been observed in vitro, ex vivo, and in vivo. In order to implicate apoptosis in the CD4 $\mathrm{T}$ cell loss seen in untreated HIV infection, then therapies which reverse the CD4 T cell decline must necessarily reduce CD4 T cell apoptosis. Since three distinct forms of apoptosis have been described in HIV infection (enhanced spontaneous apoptosis, enhanced AICD, and enhanced anti-Fas stimulated apoptosis), we therefore analyzed each of these forms of apoptosis before and during therapy.

Dramatic reductions in all three forms of apoptosis were observed in both CD4 and CD8 T cell subsets within a few days of starting therapy. Prior to antiretroviral therapy, $17.4 \%$ (range $10-21.1$ ) of CD4 T cells were undergoing spontaneous apoptosis. Within 4 days of therapy this rapidly declined to $2.6 \%$ (range $0-16.8 \% ; P=0.005$ ) (Figure 3), and further decreased by day 8 to $0.6 \%$ (range $0.2-3.1$ ), continuing at a low level throughout the period of observation (overall $P=<0.001$ ). Similarly, spontaneous CD8 $T$ cell apoptosis which was elevated before therapy with a median value of $15.0 \%$ (range $7.3-$ 58.6) fell within 4 days to $5.9 \%$ (range $0-45.7 ; P=0.05$ ) and by day 8 spontaneous apoptosis was reduced to $1 \%$ (range $0.9-4.5 \%$ ), a level that persisted throughout the period of observation (overall $P=<0.001$ ).

A similar analysis was performed in the CD4 and CD8 T cell subsets following stimulation with either anti Fas antibody or anti CD3 antibody (Figure 4). In order to differentiate changes in anti Fas or anti CD3 specific apoptosis from changes in spontaneous apoptosis, cells were coincubated in the presence of an isotype control antibody, and the amount of specific apoptosis was determined by subtracting isotype control apoptosis from the observed apoptosis following either anti Fas or anti CD3 stimulation. Prior to treatment, anti Fas stimulation resulted in $19.0 \%$ (range $1.3-73.9 \%$ ) specific apoptosis of CD4 T cells, and in $13.7 \%$ (range $1.7-86.1 \%$ ) specific CD8 $\mathrm{T}$ cell apoptosis. Similar to the findings with spontaneous apoptosis, CD4 T cell Fas specific apoptosis decreased during treatment, finally resulting in $3.5 \%$ (range $0.4-20.5$ ) specific apoptosis by day 180 , and $1.5 \%$ (range $0.1-3.8$ ) CD8 T cell specific apoptosis by day 180 (overall CD4 T cell anti Fas apoptosis, overall $P=0.03$; overall CD8 $T$ cell anti Fas apoptosis $P=0.002)$. Analysis of CD3 induced apoptosis before and after therapy revealed a similar pattern: ranging from $13.7 \%$ in CD4 T cells (range 130.2 ) before therapy to $3.2 \%$ (range $0.4-11.5$ ) after 180 days of treatment (overall $P=0.001$ ). CD3 induced AICD of CD8 $\mathrm{T}$ cell also decreased from 29\% (range 1.9-84.7) prior to treatment to $2.2 \%$ (range $0.4-4.8$ ) following 180 days of treatment (overall $P=0.03$ ).

\section{Analysis of Fas expression}

In comparison to resting CD4 T cells, activated CD4 T cells are preferentially infected by $\mathrm{HIV}^{52-54}$ and preferentially susceptible to die by Fas induced apoptosis. ${ }^{63-65}$ These observations suggest that in the context of HIV infection both increased Fas sensitivity, and increased FasL production favour CD4 T cell apoptosis.

We therefore evaluated whether changes in Fas expression could account for the decreases in apoptosis and sensitivity to apoptosis that were observed. Before initiation of therapy the median percentage of Fas positive CD8 T cells was 55\% (range 25.5-81). The percentage of Fas positive cells did not change after initiation of therapy: median percentage of Fas positive cells on day 4 was $43.4 \%$ (range $14-74.7$ ), day 8 was $47.4 \%$ (range $14.7-$ 68.8 ), on day 60 was $60.1 \%$ (range $35.9-75$ ) and on day 180 was $43.2 \%$ (range 18.6-52.1), (overall $P=\mathrm{NS}$ ). Similarly, the median percentage of CD4 T cells expressing Fas was $56.7 \%$ (range $36.5-73.3$ ) prior to therapy, $57.5 \%$ (range $43.7-78.2$ ) on day $4,49.6 \%$ (range $25.8-$ 78.8 ) on day $8,61.5 \%$ (range $34.4-85.9$ ) on day 60 and was $52.3 \%$ (range $34.6-82.2$ ) on day 180 (overall $P=\mathrm{NS}$ ).

In order to assess whether small changes in Fas expression were responsible for the observed changes in apoptosis, we correlated Fas receptor expression with measures of apoptosis, evaluating the number of Fas positive cells and amount of CD4 and CD8 T cell apoptosis that occurred spontaneously, in response to Fas ligation, or in response to CD3 stimulation. The percentage of CD4 T cells expressing Fas was not significantly associated with spontaneous CD4 $\mathrm{T}$ cell apoptosis $\left(P=\mathrm{NS}, \mathrm{R}^{2}=0.029\right)$, anti CD3 induced CD4 T cell apoptosis $\left(P=\mathrm{NS}, \mathrm{R}^{2}=0.04\right)$ or anti Fas induced CD4 $\mathrm{T}$ cell apoptosis $\left(P=\mathrm{NS}, \mathrm{R}^{2}=0.06\right)$. Similarly, the percentage of CD8 $T$ cells expressing Fas was not associated with spontaneous CD8 T cell apoptosis $\left(P=\mathrm{NS}, \mathrm{R}^{2}=0.10\right)$, and CD3 induced CD8 $\mathrm{T}$ cell apoptosis $\left(P=\mathrm{NS}, \mathrm{R}^{2}=0.04\right)$ or with anti Fas induced CD8 $\mathrm{T}$ cell apoptosis $\left(P=\mathrm{NS}, \mathrm{R}^{2}=0.02\right)$. These data suggest that in contrast to prior cross sectional data, ${ }^{31-33,36}$ in HIV infected patients followed longitudinally, changes in susceptibility to apoptosis is not a consequence of changes in Fas receptor expression.

\section{Correlation between activation and apoptosis}

Previous work by several groups has demonstrated that sensitivity towards Fas receptor mediated apoptosis is correlated with activation. ${ }^{63-65}$ In addition, HIV gp120 both directly activates CD4 T cells and has been implicated as a mechanism for priming cells towards both AICD and spontaneous apoptosis. ${ }^{49,55,66,67}$ We therefore postulated that in the context of HIV infection, decreasing sensitivity to 
apoptosis following effective therapy should correlate with changes in activation profiles. We therefore performed linear regression analyses to assess for a potential relationship between the percentage of cells coexpressing the activation markers CD38 and HLA-DR, and the percentage of apoptotic cells present either spontaneously or in response to anti Fas or anti CD3 ligation (Figure 5). Activation markers of CD4 T cells were significantly correlated with spontaneous apoptosis $\left(P=0.003, R^{2}=0.542\right)$, anti Fas induced apoptosis $(P=0.01$, $\left.\mathrm{R}^{2}=0.246\right)$ and with CD3 induced apoptosis $(P=0.001$,
$\left.\mathrm{R}^{2}=0.389\right)$. $\quad \mathrm{CD} 8 \mathrm{~T}$ cell activation profiles were also associated with spontaneous apoptosis $\left(P=0.02, \mathrm{R}^{2}=0.303\right)$ with Fas induced apoptosis $\left(P=0.01, \mathrm{R}^{2}=0.248\right)$, but not CD3 induced apoptosis $\left(P=0.06, R^{2}=0.151\right)$. Since the nature of our data set was serial longitudinal observations, in nine different patients, linear regression analyses may be affected by bias introduced by multiple comparisons of individual subjects. Therefore, since linear regression analyses suggested potential correlation between activation and apoptosis, we next performed a Liang-Zeger regression. ${ }^{68,69}$

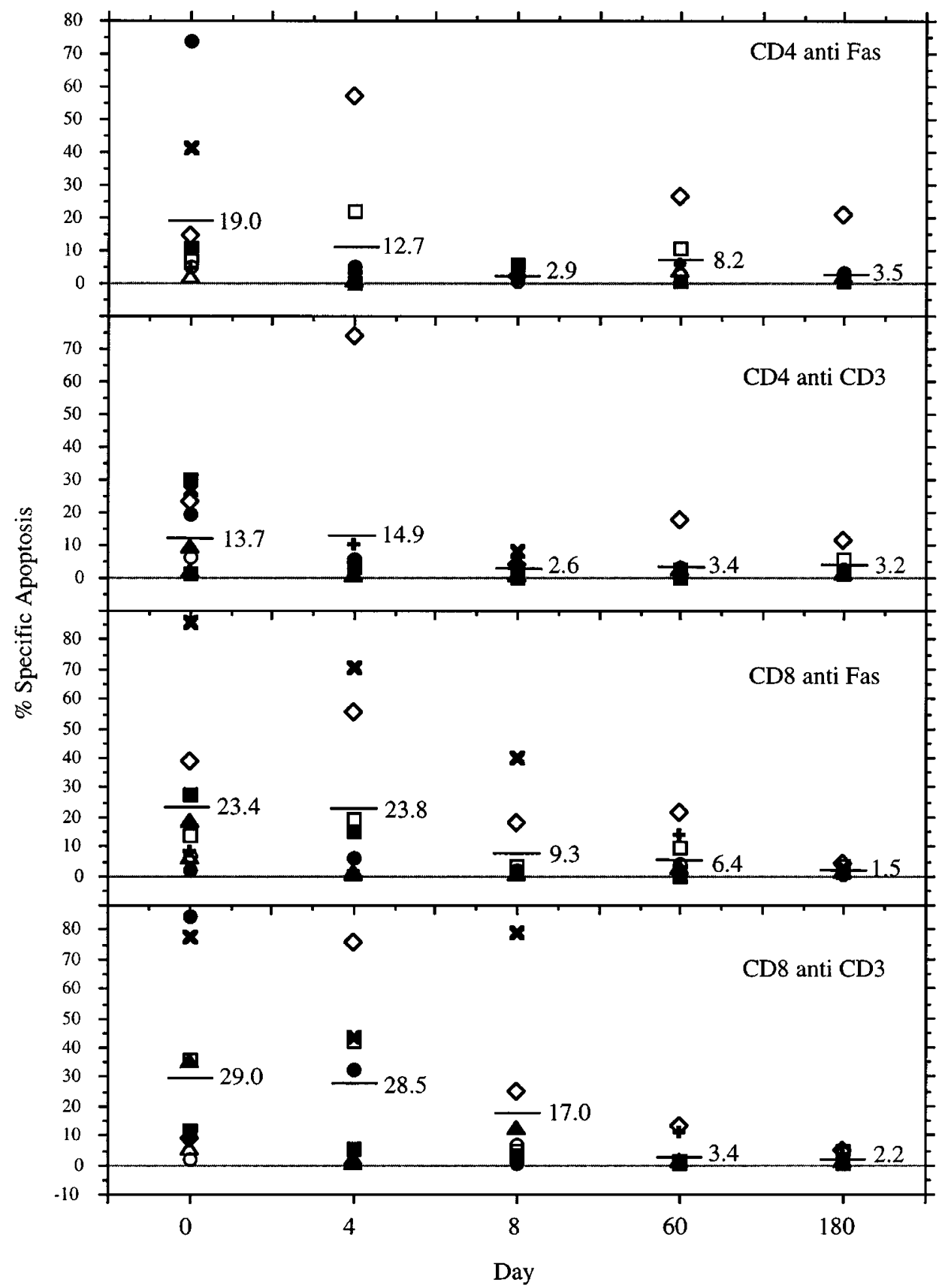

Figure 4 Analysis of anti Fas induced apoptosis and AICD. Prior to and during antiretroviral therapy, the number of CD4 (top two panels) of CD8 T cells (bottom two panels) undergoing anti Fas specific (first and third panels) or anti CD3 specific (second and fourth panels) specific apoptosis was determined using annexin V. Horizontal bars represent group means, and each symbol represents a different patient 
These analyses confirmed the association of activation markers of CD4 T cells with spontaneous apoptosis $(P=0.008)$, antiFas induced apoptosis $(P=0.001)$ and anti CD3 induced apoptosis $(P=0.005)$. Similarly, the associations of CD8 $T$ cell activation with spontaneous apoptosis $(P=0.001)$ anti Fas induced apoptosis $(P=0.001)$ and anti CD3 induced apoptosis $(P=0.001)$ were confirmed.

\section{Analysis of FLIP expression}

Our observation of decreasing Fas sensitivity without changes in Fas receptor expression, is consistent with prior observations indicating a discordance between Fas expression and Fas sensitivity. ${ }^{70,71}$ One molecular explanation for this revolves around a recently characterized protein, FLIP, (FLICE inhibitory peptide) which inhibits caspase activation. ${ }^{72}$
In resting naive $\mathrm{T}$ cells (which express Fas but are Fas resistant) FLIP is expressed at high levels, whereas activation of $T$ cells results in decreased levels of FLIP and the development of Fas susceptibility. Importantly, within PBLs, protein expression is concordent with mRNA levels. ${ }^{72}$ Since patients enrolled in our study initially have Fas expressing and Fas sensitive CD4 and CD8 T cells, we postulated that these cells would contain less FLIP content, (making them Fas sensitive) when compared to cells from uninfected donors.

FLIP expression was therefore analyzed in PBL's from six untreated HIV positive patients with high levels of spontaneous apoptosis (range $=22-61 \%$ ) and from one HIV negative volunteer with $6 \%$ spontaneous apoptosis (Figure 6). In HIV negative patients $55 \mathrm{Kd}$ FLIP was detectable in PBL's. Surprisingly, analysis of PBL's from untreated HIV infected patients revealed similar levels of FLIP expression.

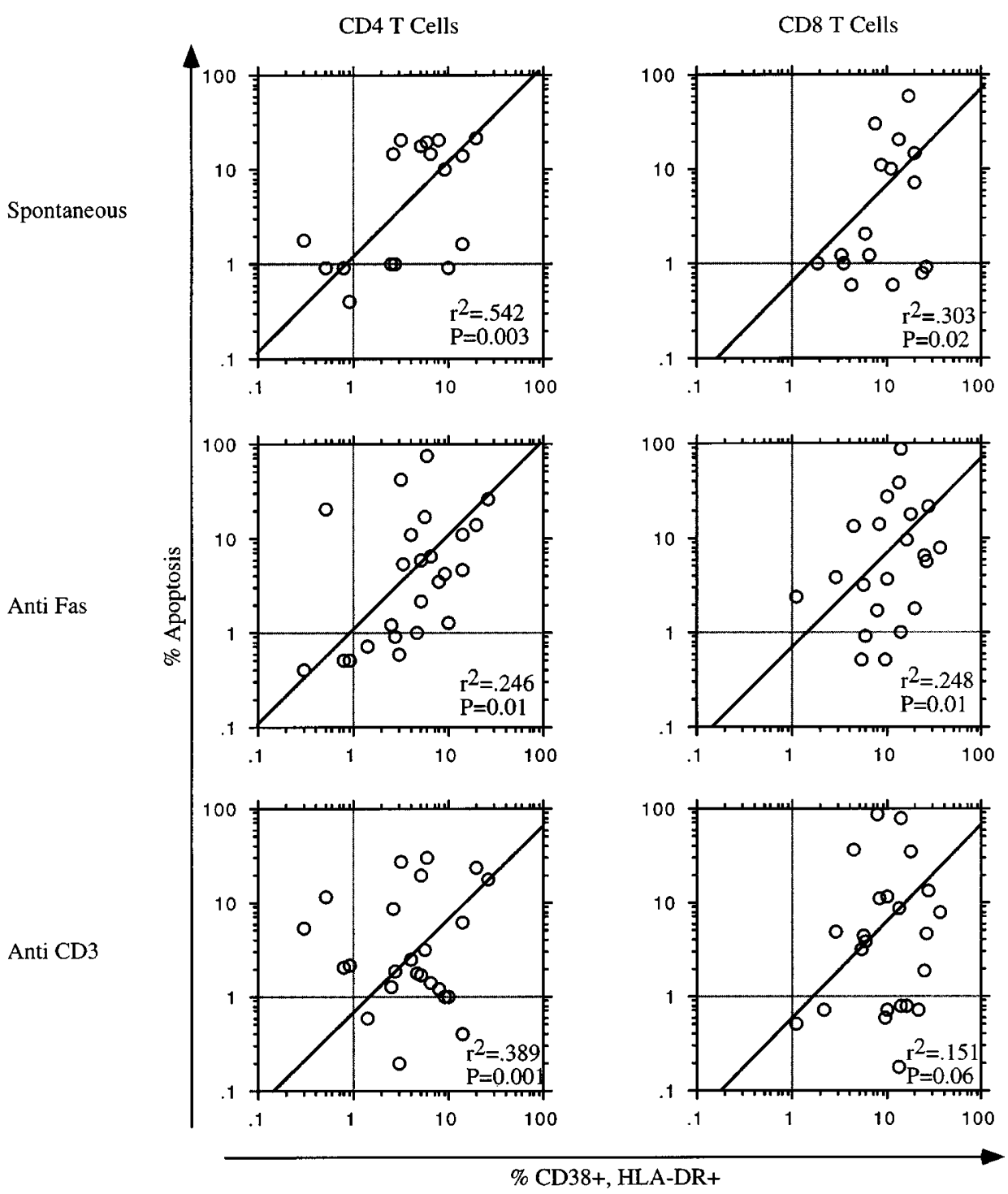

Figure 5 Correlation between apoptosis and activation profile. Linear regression analyses were performed using paired data of percentage of apoptotic cells as determined by annexin V ( $Y$ axis) versus percentage cells co-expressing CD38 and HLADR (X axis). Separate analyses were performed for CD4 T cells (left panels) and CD8 T cells (right panels). Confirmatory statistical analyses using Liang-Zeger regression was also performed (see text) 
A

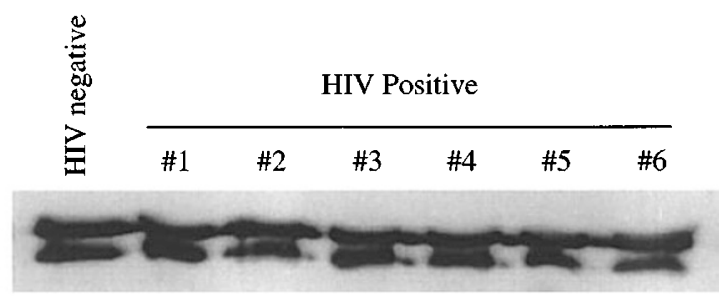

B

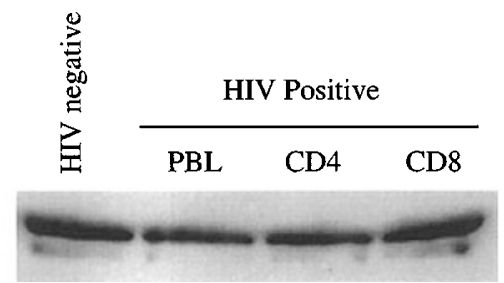

Figure 6 Analysis of FLIP expression. Whole cell lysates from either bulk PBLs (A) or purified CD4 or CD8 T lymphocytes (B) form HIV infected or uninfected patients were analyzed by Western blot analysis for intracellular FLIP content. All HIV infected patients included in these experiments had high levels of apoptosis (see text)

To determine whether differences in FLIP expression were present between $T$ cell subsets, we purified CD4+lymphocytes and CD8+lymphocytes from an HIV positive patient with high levels (46\%) of spontaneous apoptosis. No differences in FLIP expression were observed between bulk PBL's from an HIV negative control, bulk PBL's from an HIV infected but untreated patient, or either purified CD4 or CD8 T cells from the same HIV infected patient.

\section{Discussion}

It is clear that in HIV infected patients, CD4 T cell death occurs by apoptosis that may result from one of several mechanisms (see below). In each, the presence of $\mathrm{T}$ cells which are primed to undergo apoptosis favors the initiation of apoptosis, and therefore may be critical to AIDS pathogenesis. This paper defines the relationship between apoptosis, apoptosis susceptibility, viral load, and immunologic reconstitution.

Patients enrolled in our trial experienced a rapid decline in viral load, with a concomitant increase in CD4 T cell counts. At the same time, the proportion of activated $T$ lymphocytes decreased, the number of naive $T$ lymphocytes increased, and apoptosis (induced by a variety of stimuli) was reduced in a manner that correlated with activation profiles. Our results extend prior observations that apoptosis and sensitivity towards apoptosis are closely related to activation state. ${ }^{73}$ This association has been observed in cross-sectional ${ }^{57,74}$ and longitudinal studies. ${ }^{46}$ Indeed, the correlation of apoptosis with activation has been suggested as a mechanism to explain the enhanced CD4 $\mathrm{T}$ cell loss seen in HIV positive patients coinfected with other pathogens, ${ }^{75,76}$ and the lack of apoptosis in HIV infected chimpanzees (in whom activation does not occur). ${ }^{77}$ It remains unknown whether effective antiretroviral therapy, which leads to immune deactivation, is associated with decreases in apoptosis and apoptosis sensitivity. The current report addresses this question and demonstrates a significant correlation between changes in apoptosis and changes in activation. These data suggest that immune activation, perhaps due to virally encoded antigen(s), may be responsible for the enhanced susceptibility to apoptosis that is seen in HIV infected patients. Importantly, we demonstrate the reversibility of activation, which is associated with reversal of enhanced apoptosis. Together these results support an etiologic role for apoptosis as a mechanism of CD4 T cell depletion in AIDS that is efficiently reversed by therapies that lead to immunologic reconstitution. Whether the inhibition of apoptosis is due to direct antiapoptotic effects of therapy, or is due solely to immune deactivation, remains to be elucidated.

Apoptosis in patients infected with HIV has been widely studied in vitro and to a lesser extent in vivo. Most of the published literature indicates that apoptosis is highly and temporally associated to the CD4 $\mathrm{T}$ cell decline that is seen in HIV infected patients. Furthermore at least three distinct apoptotic mechanisms have been suggested. The first mechanism is modelled in vitro by direct HIV infection of CD4 T cells, in which apoptosis occurs following direct HIV infection of $T$ cells and is closely related to the kinetics of HIV replication. ${ }^{78}$ Detailed analyses have indicated that, although caspase activation occurs following direct HIV infection, ${ }^{79}$ this form of cell death is independent of Fas receptor signalling, ${ }^{80,81}$ thereby suggesting a direct role for an HIV encoded protein to activate apoptosis independent of Fas. In this regard, HIV protease, $^{82-84} \mathrm{HIV} \mathrm{vpr}^{85-87} \mathrm{HIV} \mathrm{Nef}^{88-90}$ and HIV Tat, ${ }^{91,92}$ have all been suggested as potential mediators of direct CD4 T cell induced apoptosis. In patients infected with HIV, this form of CD4 T cell death is represented by spontaneous $\mathrm{T}$ cell apoptosis. Previous studies have evaluated spontaneous apoptosis in HIV infected patients and showed that apoptosis of CD4 $\mathrm{T}$ cells was significantly increased in comparison to HIV uninfected patients. ${ }^{16,17}$ Furthermore the magnitude of apoptosis directly correlated with stage of HIV disease when examined either longitudinally ${ }^{20}$ or cross-sectionally. ${ }^{19}$ Furthermore, while spontaneous apoptosis is increased in HIV infected patients with progressive disease compared to HIV uninfected patients ${ }^{18,20}$ levels of spontaneous apoptosis in patients with long term non progressive HIV infection are similar to that of HIV negative patients. ${ }^{21,22}$ Since spontaneous apoptosis is inhibited in vitro by blocking viral replication, it is reasonable to suspect that spontaneous apoptosis in vivo would similarly be decreased. This study supports that hypothesis by showing that levels of spontaneous apoptosis revert to values seen in HIV uninfected patients within 8 days of treatment, and that within this short time frame, CD4 and CD8 $T$ cell counts increase.

AICD has been implicated as a second form of apoptosis in the pathogenesis of HIV. This form of apoptosis occurs in both HIV uninfected patients ${ }^{44,45,93-95}$ and HIV infected 
patients ${ }^{46-48,96}$ in response to $\mathrm{T}$ cell activation taking place in the absence of appropriate MHC class II antigen presentation. In this report, we confirm increased levels of AICD in HIV infected patients prior to the initiation of antiretroviral therapy. Although the precise signals responsible for AICD in patients with HIV infection are unclear, ${ }^{36,47,97,98}$ gp120 mediated activation of the CD4 receptor has been demonstrated to enhance AICD, to increase Fas susceptibility, and to increase Fas ligand expression (see above). Therefore, decreased production of viral gp120, such as would occur in the context of effective antiretroviral therapy, would be expected to result in decreased cellular activation, as a concomitant decrease in AICD. This study demonstrates striking decreases in activation and a significant correlation between the activation profile and the magnitude of AICD.

A third postulated mechanism for HIV governed apoptosis of CD4 T cells suggests that HIV infected macrophages, a source of apoptosis inducing ligands, are capable of killing apoptosis prone CD4 T cells. This mechanism has been extensively studied in vitro, ${ }^{23-30}$ and recently has been found to occur in vivo. ${ }^{40}$ FasL has been implicated in HIV pathogenesis as a molecule that is selectively upregulated in monocytes/macrophages after CD4 crosslinking ${ }^{26}$ or HIV infection. ${ }^{23,24}$ Furthermore, FasL transcripts are seen in peripheral blood mononuclear cells (that contain monocytes) from HIV infected but not HIV uninfected patients. ${ }^{99}$ This has led to a model wherein HIV infected monocytes/macrophages are a source of ligands that induce apoptosis of uninfected CD4 T cells. Data using HIV patient PBMC's, ${ }^{29}$ or macrophages infected with HIV 20,23,24,28 demonstrate an ability to selectively kill CD4 T cells, that is blocked by masking Fas receptor. Recent demonstration of a selective upregulation of FasL in lymph node macrophages from HIV infected patients supports this model. ${ }^{41}$ In untreated HIV patients, tissue levels of FasL are correlated with levels of $T$ cell apoptosis in the same tissue. After effective therapy apoptosis decreases but FasL expression does not, ${ }^{40}$ suggesting an important regulatory role for $\mathrm{T}$ cell susceptibility towards Fas mediated apoptosis. Consistent with these previous observations, our data demonstrate a dramatic change in Fas sensitivity in response to suppressed viral replication.

This report provides additional insights into the pathogenesis of HIV disease. FLIP is a recently described inhibitor of the TNF receptor superfamily induced apoptosis. ${ }^{72}$ Transfection of FLIP into cell lines blocks FasL and TRAIL (TNF related apoptosis inducing ligand) induced apoptosis (which utilize the proximal caspase FLICE) but not staurosporin induced apoptosis (which bypasses FLICE). The important correlation of apoptosis with activation suggests a potential role for FLIP in the regulation of apoptosis susceptibility that is increased in HIV infected patients. However, our observation that FLIP expression in PBL's from HIV infected individuals is the same as in PBL's from HIV uninfected individuals suggests that if FLIP is an inhibitor of FLICE then HIV mediated direct $\mathrm{T}$ cell killing occurs through a receptor independent mechanism that activates apoptosis at or distal to FLICE. Alternately, FLIP may be a prototype of a new family of apoptosis regulating protein, whose cumulative cellular effects depend upon the relative expression of each family member, as opposed to the isolated expression of one (analogous to the $\mathrm{Bcl}_{2}$ family of apoptosis regulating proteins. $^{100}$ The existence of multiple FLIP RNA species in Northern blot analyses from human tissues supports this theory. Furthermore, the presence of FLIP (short) RNA but no FLIP (short) protein in resting $T$ cells suggests an element of post transcriptional FLIP regulation. ${ }^{72}$ Lastly, recent characterization of I-FLICE ${ }^{101}$ and CLARP ${ }^{102}$ both of which have multiple transcripts in human tissues further demonstrates the complexity and multiplicity of the molecular interactions involved in the regulation of apoptosis.

Our data indicate that protease inhibitor based antiretroviral therapy results in decreased activation and decreased apoptosis, that are statistically correlated. It remains possible that HIV protease inhibitors may directly influence apoptosis, potentially in a manner which inhibits apoptosis. In support of this concept, the direct inhibitory effects of the protease inhibitor ritonavir on CTL function and on antigen presentation, demonstrate that this class of agents directly modulates immune function. ${ }^{103}$ Furthermore, several lines of evidence suggest that protease inhibitors may affect $T$ cell turnover in a manner that is independent of changes in viral load. If rebound in CD4 T cell counts are solely related to decreases in viral load, one would predict similar increases in CD4 T cell levels with similar degrees of viral suppression whether this was achieved by protease inhibitor or non-protease inhibitor based therapy. In one such trial, despite similar levels of viral suppression, therapy with $\mathrm{AZT}$ and the protease inhibitor saquinavir results in superior rises in CD4 T cell counts, after 8 and 16 weeks therapy when compared to non protease inhibitor therapy with AZT and DDC. ${ }^{104}$ In addition, recent reports describe improvements in CD4 counts despite unsuppressed viral replication in patients treated with protease inhibitor based combination antiretroviral salvage regimens. ${ }^{105-107}$ A second line of evidence which suggests that protease inhibitors directly affect $\mathrm{T}$ cell homeostasis is the observation that in patients treated with protease inhibitor based therapy, CD8 $\mathrm{T}$ cell numbers rise in a manner which is greater than that seen with non protease inhibitor based regimens. ${ }^{108}$ Together these observations support the possibility that HIV protease inhibitors may directly influence $T$ cell apoptosis.

In conclusion, this series of experiments demonstrates changes in apoptosis and its regulation which occur in response to initiation of antiretroviral therapy. Furthermore, since these changes occur both rapidly and parallel to improvements in CD4 T cell counts and activation profiles, the data provide further evidence in support of a causal role of apoptosis in CD4 T cell depletion following HIV infection. The observation that decreased spontaneous apoptosis and decreased apoptosis sensitivity is closely correlated with immune deactivation suggests that the process by which HIV activates cells also is responsible for enhancing cell susceptibility towards apoptosis. Finally, our observation that the expression of FLIP was not different between HIV positive and negative patients indicates the need for 
further studies designed to identify the mechanism(s) by which apoptosis and susceptibility to apoptosis is regulated in HIV infection.

\section{Materials and methods}

\section{Patients}

All patients attending the Ottawa Hospital (General Site) Immunodeficiency Clinic, were eligible for enrollment if they were between 1860 years of age, with a positive serologic test for HIV and a baseline HIV RNA plasma virus load of greater than or equal to 400 copies $/ \mathrm{ml}$. Patients were excluded if they had been treated with reverse transcriptase inhibitors for more than 6 months, or had been previously treated with HIV protease inhibitors. After obtaining informed consent, patients were enrolled into one of two treatment arms of a trial designed to compare the pharmacokinetics of different doses of nelfinavir and saquinavir in combination with two reverse transcriptase inhibitors. All patients evaluated in the current study received saquinavir $600 \mathrm{mg}$ tid; after 4 days, $750 \mathrm{mg}$ tid of nelfinavir was added. Eight days after starting saquinavir, two reverse transcriptase inhibitors were added. Blood was collected in heparinized tubes on days $0,1,4,8,30,60,120,180$ of the trial.

\section{Cells}

Peripheral blood mononuclear cells (PBMC) were isolated by density gradient centrifugation, using Ficoll hypaque (Pharmacia, Uppsala, Sweden). Cells were centrifuged, washed, and resuspended in RPMI 1640 (Life Technologies, Burlington, Ontario, Canada) supplemented with 10\% AB serum (Gibco Laboratories, Burlington, Ontario, Canada), penicillin, streptomycin and glutamine (Sigma-Aldrich, Oakville, Ontario, Canada) and incubated at $37^{\circ} \mathrm{C}$ in a $5 \% \mathrm{CO}_{2}$ humidified environment. Where indicated, monocytes were removed by two cycles of plastic adherence, and the resultant peripheral blood lymphocytes (PBL) populations incubated as above.

\section{Measurement of lymphocyte subsets and viral load}

CD4 and CD8 T cell counts were measured by a Federally certified independent flow cytometry facility using standardized techniques. The levels of HIV-1 RNA in plasma were quantified using a commercially available NASBA (Nucleid Acid Sequence Based Amplification) and electro-chemoluminescence (ECL) detection system (nuclisens ${ }^{\text {(im }}$ HIV QT; Organon Teknika, Durham, North Carolina, USA). This assay has a quantification limit 80 copies $/ \mathrm{ml}$ of liquid.

\section{Immunophenotyping}

Whole blood was used for immunophenotype analysis, following $Q$ prep treatment (Coulter Labs, Burlington, Ontario, Canada) according to the manufacturers' instructions. Cells were washed, and then resuspended in PBS containing $1 \mu \mathrm{g} / \mathrm{ml}$ of the indicated antibody or isotype control antibody. Thereafter cells were analyzed using a Coulter Epics XL flow cytometer, and 30000 total events were recorded. Specific fluorescence was determined after gating against an isotype control antibody and an autofluorescence tube, and colour compensation was performed using CD3FITC, CD4PE and CD45PECy5. Antibodies used for these experiments were CD4-PE, CD8-PE, CD45RA-PE-Cy5, CD62L-FITC, CD38-FITC, anti HLADR-PE-Cy5 and anti CD28-FITC; all were obtained from Coulter Labs (Burlington, Ontario, Canada).

\section{Induction and measurement of apoptosis}

To measure anti Fas induced apoptosis, cells were stimulated with either $1 \mu \mathrm{g} / \mathrm{ml}$ of agonistic anti Fas IgM $(\mathrm{CH} 11$, Coulter Labs, Burlington, Ontario, Canada) or with an isotype matched control antibody (gc323, Coulter Labs, Burlington, Ontario, Canada). To measure AICD induced by anti CD3 treatment, cells were incubated with $1 \mu \mathrm{g} / \mathrm{ml}$ of anti CD3 (HIT3.a; Pharmingen, Mississauga, Ontario, Canada), or with an isotype control (IgG2a; Becton Dickinson, Mississauga, Ontario, Canada). To determine spontaneous apoptosis, cells were immediately analyzed for apoptosis. Following $4 \mathrm{~h}$ of incubation with antibody (or immediately in the case of spontaneous apoptosis), cells were gently harvested, washed with PBS, and incubated sequentially with $10 \mu \mathrm{g} /$ million cells of immune globulin (Sigma Aldrich, Oakville, Ontario, Canada), then either $1 \mu \mathrm{g} / \mathrm{million}$ cells of CD4 PE (13B8.2; Coulter, Burlington, Ontario, Canada) or $1 \mu \mathrm{g} /$ million cells of CD8 PE (B9.11; Coulter, Burlington, Ontario, Canada) (or isotype control; $1 \mathrm{gG1}$ Becton Dickinson, Mississauga, Ontario, Canada). Thereafter cells were stained with annexin V-FITC (BioWhittaker Inc., Walkersville, MD, USA) according to the manufacturers instructions. To exclude dead cells (which are annexin positive) forward versus side scatter plots were gated to include only the viable population, and the expression of CD4, CD8 and annexin determined. This method has previously been validated, ${ }^{20,109}$ and prior to initiation of this study its sensitivity confirmed in comparison to the combination of annexin - V FITC and Propidium iodide (data not shown). To determine Fas specific and CD3 specific apoptosis, the amount of apoptosis observed after isotype antibody treatment was subtracted from the amount of apoptosis present after either anti Fas or anti CD3 treatment. For each analysis, 30000 total events were collected using a Coulter Epics XL flow cytometer.

\section{Analysis of FLIP expression}

FLIP expression was analyzed by Western blot as previously described. ${ }^{72}$ Briefly, cells were harvested by Ficoll hypaque as above, and either bulk PBL's or purified CD4 or CD8 T cell populations were analyzed for FLIP content. For purification of CD4 or CD8 T cell populations, monocyte depleted PBL's were first incubated with either CD4 monoclonal antibody (Pharmingen) or CD8 monoclonal antibody (Pharmingen) for 30 min on ice. Cells were then washed in PBS - 1\% BSA and incubated with a secondary anti mouse biotinylated antibody for 30 min on ice. Following washing in PBS 1\% BSA, purified CD4 or CD8 $\mathrm{T}$ cell populations were recovered using an avidin column, according to the manufacturers' instructions (Cell Pro, Ceprate LC). The resultant CD4 or CD8 T cell populations were at least $95 \%$ pure as measured by flow cytometry. The indicated cell populations were then lysed in PBS, $1 \%$ NP40 with $0.35 \mathrm{mg} / \mathrm{ml} \mathrm{PMSF}, 9.4 \mu \mathrm{g} / \mathrm{ml}$ leupeptin, $13.7 \mu \mathrm{g} / \mathrm{ml}$ pepstatin A and $10 \mu \mathrm{g} / \mathrm{ml}$ aprotinin. Fifty microliters of lysis buffer were used for every million cells, and lysis was performed on ice for $5 \mathrm{~min}$. Cell lysates were then assayed for protein content using a Bradford technique (Biorad) and $10 \mu \mathrm{g}$ of lysates were separated on a $12 \%$ polyacrylamide gel. Following semi dry transfer, membranes were blocked in PBS $0.1 \%$ tween containing $5 \%$ skim milk. FLIP was detected using a 1:1000 dilution of anti-FLIP antibody AL129 at $4^{\circ} \mathrm{C}$ overnight. A secondary anti rabbit HRP conjugated antibody (Amersham Laboratories) was then used, and bands were visualized using ECL (Amersham Laboratories).

\section{Statistics}

Comparisons of parameters measured at different time points were analyzed by ANOVA to assess for overall effects of drug treatment. 
Thereafter paired Student's $t$-tests were performed to identify differences between individual time points. Linear regression analyses comparing paired data points (e.g. Fas expression and \% apoptosis) were analyzed by Spearman correlation. If the linear regression analyses suggested potential correlation, then a LiangZeger regression ${ }^{68,69}$ was performed. This form of analysis was developed specifically for analyzing longitudinal data using regression models. For each subject, a regression coefficient is estimated for each variable. If the data sets are truly independent (i.e. not correlated) then the mean regression coefficient will be zero (i.e. the null hypothesis). Regression coefficients are directly compared using a Mann Whitney statistic for non parametric data, and the significance level determined. All analyses were done using Statview 4.0 (Abacus Concepts, Berkley CA, USA).

\section{Acknowledgements}

This work was supported by grants from Physicians Services Incorporated (to A.D. Badley, \#97-30) the Doris Duke foundation (to A.D. Badley, \#T98026), the Medical Research Council of Canada (to J.B. Angel, \#PA-14913) and the Canadian Foundation for AIDS Research (to J.B. Angel), and a portion of the research was supported by Roche Laboratories. D.W. Cameron is an Ontario Ministry of Health Career Scientist (\#02484). Informed consent was obtained from patients and the protocol was reviewed by the Ottawa General Hospital/University of Ottawa Ethics Review Committee. The authors gratefully acknowledge the efforts of I. Seguin, N. Hawley-Foss and Drs G. Garber, S. Cassol, Y. Khaliq, K. Gallicano and J. Sahai for their roles in this study. The efforts of S. Giguère during manuscript preparation are gratefully acknowledged.

\section{References}

1. Angel JB, Kumar A, Parato K, Filion LG, Diaz-Mitoma F, Daftarian P, Pham B, Sun E, Leonard JM and Cameron DW (1998) Improvement in cell-mediated immune function during potent anti-human immunodeficiency virus therapy with Ritonavir plus Saquinavir. J. Infect. Dis. 177: 898-904

2. Flexner C (1998) HIV-protease inhibitors. N. Engl. J. Med. 338: 1281-1292

3. Schapiro JM, Winters MA, StewartF, Bradley E, Norris J, Kozal MJ and Merigan TC (1996) The effect of high-dose Saquinavir on viral load and CD4 ${ }^{+}$T-cell counts in HIV-infected patients. Ann. Intern. Med. 124: 1039-1050

4. Cameron DW, Heath-Chiozzi M, Danner S, Cohen C, Kravcik S, Maurath C, Sun E, Henry D, Rode R, Potthoff A and Leonard J (1998) Randomised placebocontrolled trial of ritonavir in advanced HIV-1 disease. Lancet 351: 543-549

5. Li CJ, Friedman DJ, Wang C, Metelev V and Pardee AB (1995) Induction of apoptosis in uninfected lymphocytes by HIV-1 Tat protein. Science 268: 429431

6. Lederman MM, Connick E, Landay A, Kuritzkes DR, Spritzler J, St. Clair M, Kotzin BL, Fox L, Heath Chiozzi M, Leonard JM, Rousseau F, Wade M, Roe J, Martinez A and Kessler H (1998) Immunologic responses associated with 12 weeks of combination antiretroviral therapy consisting of Zidovudine, Lamivudine, and Ritonavir: Results of AIDS Clinical Trials Group Protocol 315. J. Infect. Dis. 178: 70-79

7. Pakker NG, Notermans DW, de Boer RJ, Roos MTL, de Wolf F, Hill A, Leonard JM, Danner SA, Miedema F and Schellekens PTA (1998) Biphasic kinetics of peripheral blood T cells after triple combination therapy in HIV-1 infection: A composite of redistribution and proliferation. Nature Med. 4: 208-214

8. Autran B, Carcelain G, Lis TS, Blanc C, Mathez D, Tubiana R, Katlama C, Debré $P$ and Leibowitch J (1997) Positive effects of combined antiretroviral therapy on $\mathrm{CD}^{+} \mathrm{T}$ cell homeostasis and function in advanced HIV disease. Science 277 : $112-116$

9. Gorochov G, Neumann AU, Kereveur A, Parizot C, Li T, Katlama C, Karmochkine M, Raguin G, Autran B and Debré P (1998) Perturbation of $\mathrm{CD}^{+}$and $\mathrm{CD} 8^{+} \mathrm{T}$-cell repertoires during progression to AIDS and regulation of the $\mathrm{CD}^{+}$repertoire during antiviral therapy. Nature Med. 4: 215-221
10. Kempf DJ, Marsh KC, Kumar G, Rodrigues AD, Denissen JF, McDonald E, Kuklka MJ, Hsu A, Grannemen GR, Baroldi PA, Sun E, Pizzuti D, Plattner JJ, Norbeck DW and Leonard JM (1997) Pharmacokinetic enhancement of inhibitors of the human immunodeficiency virus protease by coadministration with ritonavir. Antimicrob. Agents Chemother. 41: 654-660

11. Badley AD, Dockrell D and Paya CV (1997) Apoptosis in AIDS. In Advances in Pharmacology, volume 4. Eds Kaufmann Scott H. 271-294

12. Clerici M, Sarin A, Henkart PA and Shearer GM (1997) Apoptotic cell death and cytokine dysregulation in human immunodeficiency virus infection: pivotal factors in disease progression. Cell Death Differ. 4:699-706

13. Peter ME, Ehret A, Berndt C and Krammer PH (1997) AIDS and the death receptors. Brit. Med. Bul. 52: 604-616

14. Smith CA, Farrah T and Goodwin RG (1994) The TNF receptor superfamily of cellular and viral proteins: activation, costimulation, and death. Cell 76: 959962

15. Shimizu T and Pommier Y (1996) DNA fragmentation induced by protease activation in p53-null human leukemia HL60 cells undergoing apoptosis following treatment with the topoisomerase 1 inhibitor campothecin: cell-free system studies. Exp. Cell Res. 226: 292-301

16. Laurent-Crawford AG, Krust B, Muller S, Riviere Y, Rey-Culle MA, Bechel JM, Montagnier L and Howanessian AG (1991) The cytopathic effect of HIV is associated with apoptosis. Virol. 185: 829-839

17. Meyaard L, Otto SA, Jonker RR, Mijnster MJ, Keet RPM and Miedema F (1992) Programmed cell death of T cells in HIV infection. Science 257: 217-219

18. Prati E, Gorla R, Malacarne F, Airo P, Brugnoni D, GargiuloF, Tebaldi A, Castelli F, Carosi G and Cattaneo R (1997) Study of spontaneous apoptosis in $\mathrm{HIV}^{+}$ patients: Correlation with clinical progression and T cell loss. AIDS Res. Hum. Retro. 13: 1501-1508

19. Patki AH, Georges DL and Lederman MM (1997) CD4 ${ }^{+}$-T-cell counts, spontaneous apoptosis, and Fas expression in peripheral blood mononuclear cells obtained from human immunodeficiency virus type 1-infected subjects. Clin. Diag. Lab. Immunol. 4: 736-741

20. Samuelsson A, Brostrom C, van Dijk N, Sonnerborg A and Chiodi F (1997) Apoptosis of $\mathrm{CD}^{+}$and $\mathrm{CD} 19^{+}$cells during human immunodeficiency virus type 1 infection - correlation with clinical progression, viral load, and loss of humoral immunity. Virol. 238: 180-188

21. LieglerTJ, Yonemoto W, Elbeik T, VittinghoffE, Buchbinder SP and Greene WC (1998) Diminished spontaneous apoptosis in lymphocytes from human immunodeficiency virus-infected long-term nonprogressors. J. Infect. Dis. 178: $669-679$

22. Franceschi C, Grazia Franceschini M, Boschini A, Trenti T, Nuzzo C, Castellani G, Smacchia C, De Riezo B, Roncaglia R, Portolani M, Pictrosemoli P, Meacci M, Pecorari M, Sabbatini A, Malorni W and Cossarizza A (1997) Phenotypic characteristics and tendency to apoptosis of peripheral blood mononuclear cells from HIV+long term non progressors. Cell Death Differ. 4: 815-823

23. Badley AD, McElhinny JA, Leibson PJ, Lynch DH, Alderson MR and Paya CV (1996) Upregulation of Fas ligand expression by human immunodeficiency virus in human macrophages mediates apoptosis of uninfected T lymphocytes. J. Virol. 70: 199-206

24. Badley AD, Dockrell D, Simpson M, Schut R, Lynch DH, Leibson P and Paya CV (1997) Macrophage-dependent apoptosis of CD4 ${ }^{+}$T lymphocytes from HIVinfected individuals is mediated by FasL and tumor necrosis factor. J. Exp. Med. 185: 55-64

25. Cottrez F, Manca F, Dalgleish AG, Arenzana-Seisdedos F, Capron A and Groux $\mathrm{H}$ (1997) Priming of human $\mathrm{CD}^{+}$antigen-specific T cells to undergo apoptosis by HIV-infected monocytes. J. Clin. Invest. 99: 257-266

26. Oyaizu N, Adachi Y, Hashimoto F, McCloskey TW, Hosaka N, Kayagaki N, Yagita $\mathrm{H}$ and Pahwa S (1997) Monocytes express Fas ligand upon CD4 crosslinking and induce $\mathrm{CD}^{+} \mathrm{T}$ cells apoptosis. J. Immunol. 158: 2456-2463

27. Wu MX, Daley JF, Rasmussen RA and Schlossman SF (1995) Monocytes are required to prime peripheral blood T cells to undergo apoptosis. Proc. Natl. Acad. Sci. USA 92: 1525-1529

28. Orlikowsky T, Wang Z, Dudhane A, Horowitz H, Riethmuller G and Hoffman MK (1997) Cytotoxic monocytes in the blood of HIV type 1-infected subjects destroy targeted T cells in a CD95-dependentfashion. AIDS Res. Hum. Retro. 13:953960

29. Nardelli B, Gonzalez CJ, Schecter M and Valentine FT (1995) CD4 ${ }^{+}$blood lymphocytes are rapidly killed in vitro by contact with autologous human immunodeficiency virus-infected cells. Proc. Natl. Acad. Sci. USA 92: 73127316 
30. Herbein G, Van Lint C, Lovett JL and Verdin E (1998) Distinct mechanisms trigger apoptosis in human immunodeficiency virus type 1-infected and in uninfected bystander T lymphocytes. J. Virol. 72: 660-670

31. Gehri R, Hahn S, Rothen M, Steurerwald M, Nuesch Rand Erb P (1996) The Fas receptor in HIV infection: expression on peripheral blood lymphocytes and role in the depletion of T cells. AIDS 10: $9-16$

32. Aries SP, Schaaf B, Muller C, Dennin RH and Dalhoff K (1995) Fas (CD95) expression on $\mathrm{CD}^{+} \mathrm{T}$ cells from HIV-infected patients increases with disease progression. J. Mol. Med. 73: 591-593

33. Silvestris $F$, Cafforio $P$, Frassanito MA, Tucci M, Romito A, Nagata $S$, Dammacco $F(1996)$ Overexpression of Fas antigen on T cells in advanced HIV1 infection: differential ligation constantly induces apoptosis. AIDS 10: $131-$ 141

34. Kobayashi N, Hamamoto Y, Yamamoto N, Ishii A, Yonehara M and Yonehara S (1990) Anti-Fas monoclonal antibody is cytocidal to human immunodeficiency virus-infected cells without augmenting viral replication. Proc. Natl. Acad. Sci. USA 87: $9620-9624$

35. Westendorp MO, Frank R, Ochsenbauer K, Stricker K, Dhein J, Walczak H, Debatin K-M and KrammerPH(1995) Sensitization of T cells to CD95-mediated apoptosis by HIV-1 Tat and gp120. Nature 375: 497-500

36. Katsikis PD, Wunderlich ES, Smith CA, Herzenberg LA and Herzenberg LA (1995) Fas antigen stimulation induces marked apoptosis of T lymphocytes in human immuno-deficiency virus-infected individuals. J. Exp. Med. 181:20292036

37. Amendola A, Gougeon M-L, Poccia F, Bondurand A, Fesus L and Piacentini M (1996) Induction of 'tissue' transglutaminase in HIV pathogeneis: Evidence for high rate of apoptosis of $\mathrm{CD} 4^{+} \mathrm{T}$ lymphocytes and accessory cells in lymphoid tissues. Proc. Natl. Acad. Sci. USA 93: 11057-11062

38. Finkel TH, Tudor-Williams G, Banda NK, Cotton MF, Curiel T, Monks C, Baba TW, Ruprecht RM and Kupfer A (1995) Apoptosis occurs predominantly in bystander cells and not in productively infected cells of HIV-and SIV-infected lymph nodes. Nature Med. 1: 129-134

39. Muro-Cacho CA, Pantaleo G and Fauci AS (1995) Analysis of apoptosis in lymph nodes of HIV-infected persons. J. Immunol. 154: 5555-5566

40. Badley AD, Dockrell DH, Algeciras A, Ziesmer S, Landay A, Lederman MM, Connick E, Kessler H, Kuritzkes D, Lynch DH, Roche P, Yagita H and Paya CV (1998) In vivo analysis of Fas/FasL interactions in HIV-infected patients. J. Clin. Invest. 102: 79-87

41. Dockrell DH, Badley AD, Villacian JS, Heppelmann CJ, Algeciras A, Ziesmer S, Yagita H, Lynch DH, Roche PC, Leibson PJ and Paya CV (1998) The expression of Fas ligand by macrophages and its upregulation by human immunodeficiency virus infection. J. Clin. Invest. 101: 2394-2405

42. Giorgi JV and Detels R (1989) T-cell subset alterations in HIV-infected homosexual men: NIAID multicenter AIDs cohort study. Clin. Immunol. Immunopathol. 52: 10-18

43. Giorgi JV, Liu Z, Hultin LE, Cumberland WG, Hennessen K and Detels R (1993) Elevated levels of $\mathrm{CD} 38+\mathrm{CD} 8+$ cells in HIV infection add to the prognostic value of low CD4+ T cell levels: results of 6 years follow-up. J. Acquir. Immune Defic. Syndr. 6: 904-912

44. Dhein J, Walczak H, Baumler C, Debatin K-M and Krammer PH (1995) Autocrine T-cell suicide mediated by APO-1/(Fas/CD95). Nature 373: $438-441$

45. Alderson MR, Tough TW, Davis-Smith T, Braddy S, Falk B, Schooley KA, Goodwin RG, Smith CA, Ramsdell F and Lynch DH (1995) Fas ligand mediates activation-induced cell death in human T lymphocytes. J. Exp. Med. 181: 71-77

46. Gougeon ML, Lecoeur H, Dulioust A, Enouf MG, Crouvoiser M, Goujard $C$, Debord T and Montagnier L (1996) Programmed cell death in peripheral lymphocytes from HIV-infected persons. J. Immunol. 156: $3509-3520$

47. Katsikis PD, Garcia-Ojeda ME, Torres-Roca JF, Tijoe IM, Smith CA, Herzenberg LA and Herzenberg LA (1997) Interleukin-1 $\beta$ converting enzyme-like protease involvement in Fas-induced and activation-induced peripheral blood T cell apoptosis in HIV infection. TNF-related apoptosisinducing ligand can mediate activation-induced T cell death in HIV infection. J. Exp. Med. 186: $1365-1372$

48. Katsikis PD, Garcia-Ojeda MC, Wunderlich ES, Smith CA, Yagita H, Okumura K, Kayagaki N, Alderson M, Herzenberg LA and Herzenberg LA (1996) Activation-induced peripheral blood T cell apoptosis is Fas independent in HIVinfected individuals. Int. Immunol. 8: 1311-1317
49. Algeciras A, Dockrell DH, Lynch DH and Paya CV (1998) CD4 regulates susceptibility to Fas ligand- and tumor necrosis factor-mediated apoptosis. J. Exp. Med. 187: 711-720

50. Giorgi JV, Ho HN, Hirji K, Chou CC, Hultin LE, O'Rourke S, ParkL, Margolick JB, Ferbas J and Phair JP (1994) CD8+ lymphocyte activation at human immunodeficiency virus type 1 seroconversion: development of HLA-DR+ CD38-CD8+ cells is associated with subsequent stable CD4+ cell levels. J. Infect. Dis. 170: $775-781$

51. Levacher M, HulstaertF, Tallet S, Ullery S, Pocidalo JJ and Bach BA (1992) The significance of activation markers on CD8 lymphocytes in human immunodeficiency syndrome: staging and prognostic value. Clin. Exp. Immunol. 90: 376-382

52. Woods TC, Roberts BD, Butera ST and Folks TM (1997) Loss of inducible virus in CD45RA naive cells after human immunodeficiency virus- 1 entry accounts for preferential viral replication in CD45RO memory cells. Blood 89: $1635-$ 1641

53. Spina CA, Prince HE and Richman DD (1997) Preferential replication of HIV-1 in the CD45RO memory cell subset of primary CD4 lymphocytes in vitro. J. Clin. Invest. 99: 1774-1785

54. Roederer M, Raju PA, Mitra DK, Herzenberg LA and Herzenberg LA (1997) HIV does not replicate in naive CD4 T cells stimulated with CD3/CD28. J. Clin. Invest. 99: 1555-1564

55. Banda NK, Bernier J, Kurahara DK, Kurrle R, Haigwood N, Sekaly R-P and Finkel TH (1992) Cross-linking CD4 by human immunodeficiency virus gp 120 primers T cells for activation-induced apoptosis. J. Exp. Med. 176: 1099-1106

56. Oyaizu N, McCloskey TW, Coronesi M, Chirmule VS, Kalyanaraman VS and Pahwa S (1993) Accelerated apoptosis in peripheral bood mononuclear cells (PBMCs) from human immunodeficiency virus type-1 infected patients and in CD4 cross-linked PBMCs from normal individuals. Blood 82: 3393-3400

57. Roederer M, Dubs JG, Anderson MT, Raju PA, Herzenberg LA and Herzenberg LA (1995) CD8 naive T cells decrease progressively in HIV-infected adults. J. Clin. Invest. 95: 2061-2066

58. Jenkins MK, Taylor PS, Norton SD and Urdahl KB (1991) CD28 delivers a costimulatory signal involved in antigen-specific IL-2 production by human $\mathrm{T}$ cells. J. Immunol. 147: 2461-2466

59. Azuma M, Cayabyak M, Buck D, Phillips JH and Lanier LL (1992) CD28 interaction with $\mathrm{B} 7$ costimulates primary allogeneic proliferative responses and cytotoxicity mediated by small, resting T lymphocytes. J. Exp. Med. 175: $353-$ 360

60. Caruso A, Cantalamessa A, Licenziati S, Peroni L, Prati E, Martinelli F, Canaris AD, Folghera S, Gorla R, Balsari A and Turano A (1994) Expression of CD28 on $\mathrm{CD} 8+$ and CD4+ lymphocytes during HIV infection. Scandinavian J. Immunol. 40: $485-490$

61. Choremi-Papadopoulou H, Viglis V, Gargalianos P, Kordossis T, IniotakiTheodoraki A and Kosmidis J (1994) Downregulation of CD28 surface antigen on CD4+ and CD8+ T lymphocytes during HIV-1 infection. J. Acquir. Immune. Defic. Syndr. 7: 245-253

62. Brinchmann JE, Dobloug JE, Heger BH, Haheim LL, Sannes M and Egeland T (1994) Expression of costimulatory molecule CD28 on T cells in human immunodeficiency virus type 1 infection: functional and clinical correlations. J. Infect. Dis. 169: 730-738

63. Fournel S, Genestier L, RobinetE, Flacher M and Revillard J-P (1996) Human T cells require IL-2 but not $G_{1} / S$ transition to acquire susceptibility to Fasmediated apoptosis. J. Immunol. 157: 4309-4315

64. Mollereau B, Blanchard D, Déas O, Dumont C, Métivier D, Bernard A, McGrew JT, Charpentier B, Vazquez A and Senik A (1997) Relationship between proliferation and susceptibility to CD95- and CD2-mediated apoptosis in stimulated primary T lymphocytes. J. Immunol. 159: 2668-2677

65. Miyawaki T, Uehara T, Nibu R, Tsuji T, Yachie A, Yonehara S and Taniguchi N (1992) Differential expression of apoptosis-related Fas antigen on lymphocyte subpopulations in human peripheral blood. J. Immunol. 149: 3753-3758

66. Lu Y, Koga Y, Tanaka K, Sasaki M, Kimura G and Nomoto K (1994) Apoptosis induced in $\mathrm{CD}^{+}$cells expressing gp160 of human immunodeficiency virus type 1. J. Virol. 68: 390-399

67. Wang Z, Dudhane A, Orlikowsky T, Clarke K, Li X, Darzynkiewicz Z and Hoffmann MK (1994) CD4 engagement induces Fas antigen-dependent apoptosis of T cells in vivo. Eur. J. Immunol. 24: 1549-1552

68. Liang K-Y and Zeger S (1986) Longitudinal data analysis using generalized linear models. Biometrika 73: 13-22 
69. Zeger SL and Liang K-Y (1986) Longitudinal data analysis for discrete and continuous outcomes. Biometrics 42: 121-130

70. Nagata $S$ (1997) Apoptosis by death factor. Cell 88: 355-365

71. Klas C, Debatin KM, Jonker RR and Krammer PH (1993) Activation interferes with the APO-1 pathway in mature human $\mathrm{T}$ cells. Int Immunol. 5: 625-630

72. Irmler M, Thome M, Hahne M, Schneider P, Hofmann K, Steiner V, Bodmer J-L, Schroter M, Burns K, Mattmann C, Rimoldi D, French LE and Tschopp J (1997) Inhibition of death receptor signals by cellular FLIP. Nature 388: 190-195

73. Copeland KF and Heeney JL (1996) T helper cell activation and human retroviral pathogenesis. Microbiol. Rev. 60: 722-742

74. Karmochkine M, Parizot C, Calvez V, Coutellier A, Herson S, Debre P and Gorochov G (1998) Susceptibility of peripheral blood mononuclear cells to apoptosis is correlated to plasma HIV load. J. AIDS 17: 419-423

75. Blanchard A, Montagnier L and Gougeon ML (1997) Influence of microbial infections on the progression of HIV disease. Trends in Microbiol. 5: 326-331

76. Cottrez F, Capron A and Groux H (1996) Selective CD4+ cell depletion afte specific activation in HIV-infected individuals; protection by anti-CD28 monoclonal antibodies. Clin. Exp. Immunol. 105: 31-38

77. Gougeon ML, Lecoeur H, Boudet F, Ledru E, Marzabal S, Boullier S, Roue R, Nagata S and Heeney J (1997) Lack of chronic immune activation in HIVinfected chimpanzees correlates with the resistance of T cells to Fas/Apo(CD95)-induced apoptosis and preservation of a T helper 1 phenotype. J. Immunol. 158: 2964-2976

78. Zhang Y, Fadeel B, Hodara V and Fenyo E (1997) Induction of apoptosis by primary HIV-1 isolates correlates with productive infection in peripheral blood mononuclear cells. AIDS 11: 1219-1225

79. Glynn JM, McElligott DL and Mosier DE (1996) Apoptosis induced by HIV infection in $\mathrm{H} 9 \mathrm{~T}$ cells is blocked by ICE-family protease inhibition but not by a Fas(CD95) antagonist. J. Immunol. 157: 2754-2758

80. Noraz N, Gozlan J, Corbeil J, Brunner T and Spector SA (1997) HIV-induced apoptosis of activated primary $\mathrm{CD} 4^{+}$T lymphocytes is not mediated by Fas-Fas ligand. AIDS 11: $1671-1680$

81. Gandhi RT, Chen BK, Straus SE, Dale JK, Lenardo MJ and Baltimore D (1998) HIV-1 directly kills $C D 4^{+} \mathrm{T}$ cells by a Fas-independent mechanism. J. Exp. Med. 187: 1113-1122

82. Konvalinda J, Litterst MA and Welker R (1995) An active-site mutation in the human immunodeficiency virus type 1 proteinase $(P R)$ causes reduced PR activity and loss of PR-mediated cytotoxicity without apparent effect on virus maturation and infectivity. J. Virol. 69: 7180-7186

83. Tomasselli AG, Hui JO, Adams L, Chosay J, Lowery D, Greenberg B, Yem A Deibel MR, Zurcher-Neely H and Heinrickson RL (1991) Actin, troponin C alzheimer amyloid precursor protein and pro-interleukin $1 \beta$ as substrates of the protease from human immunodeficiency virus. J. Biol. Chem. 266: 14548 14553

84. Strack PR, West Frey M, Rizzo CJ, Cordova B, George HJ, Meade R, Ho SP, Corman J, Tritch R and Korant BD (1996) Apoptosis mediated by HIV protease is preceded by cleavage of Bcl-2. Proc. Natl. Acad. Sci. USA 93: 9571-9576

85. Poon B, Grovit-Ferbas K, Stewart SA and Chen ISY (1998) Cell cycle arrest by Vpr in HIV-1 virions and insensitivity to antiretroviral agents. Science 281 : 266-269

86. Stewart SA, Poon B, Jowett JBM and Chen ISY (1997) Human immunodeficiency virus type $1 \mathrm{Vpr}$ induces apoptosis following cell cycle arrest. J. Virol. 71: 5579-5592

87. YaoX-J, Mouland AJ, Subbramanian RA, ForgetJ, Rougeau N, Bergeron D and Cohen EA (1998) Vpr stimulates viral expression and induces cell killing in human immunodeficiency virus type 1 -infected dividing Jurkat T cells. J. Virol. 72: $4686-4693$

88. Baur AS, Sawai ET, Dazin P, Fantl WJ, Cheng-Mayer C and Peterlin BM (1994) HIV-1 Nef leads to inhibition or activation of T cells depending on its intracellular localization. Immunity 1: 373-384

89. Greenway A, Azad A and McPhee D (1995) Human immunodeficiency virus type 1 Nef protein inhibits activation pathways in peripheral blood mononuclear cells and T-cell lines. J. Virol. 69: 1842-1850
90. Okada H, Takei R and Tashiro M (1997) Nef protein of HIV-1 induces apoptotic cytolysis of murine lymphoid cells independently of CD95 (Fas) and its suppression by serine/threonine protein kinase inhibitors. FEBS Letters 417: $61-64$

91. McCloskey TW, Ott M, Tribble E, Khan SA, Teichberg S, Paul MO, Pahwa S, Verdin Eand Chirmule N (1997) Dual role of HIV Tat in regulation of apoptosis in T cells. J. Immunol. 158: 1014-1019

92. LiTS, Tubiana R, Katlama C, Calvez V, Ait Mohand Hand Autran B(1998) Longlasting recovery in CD4 T-cell function and viral-load reduction after highly active antiretroviral therapy in advanced HIV-1 disease. Lancet 351: 1682 1686

93. Hanabuchi S, Koyanagi M, Kawasaki A, Shinohara N, Matsuzawa A, Nishimura Y, Kobayashi Y, Yonehara S, Yagita H and Okumura K(1994) Fas and its ligand in a general mechanism of T-cell-mediated cytotoxicity. Proc. Natl. Acad. Sci. USA 91: 4930-4934

94. Yang BY, Mercep M, Ware CF and Ashwell JD (1995) Fas and activationinduced Fas ligand mediate apoptosis of T cell hybridomas: Inhibition of Fas ligand expression by retinoic acid and glucocorticoids. J. Exp. Med. 181:16731682

95. Ju S-T, Panka DJ, Cui H, Ettinger R, El-Khatib M, Sherr DH, Stanger BZ and Marshak-Rothstein A (1995) Fas (CD95)/Fas L interactions required for programmed cell death after T-cell activation. Nature 373: 444-448

96. Groux H, Torpier G, Monte D, Mouton Y, Capron A and Ameisen JC (1992) Activation-induced death by apoptosis in $\mathrm{CD}^{+}{ }^{+} \mathrm{T}$ cells from human immunodeficiency virus-infected asymptomatic individuals. J. Exp. Med. 175: $331-340$

97. Jeremias I, Herr I, Boehler T and Debatin K-M (1998) TRAIL/Apo-2-ligandinduced apoptosis in human T cells. Eur. J. Immunol. 28: 143-152

98. Kaplan D and Sieg S (1998) Role of the Fas/Fas ligand apoptotic pathway in human immunodeficiency virus type 1 disease. J. Virol. 72: 6279-6282

99. Mitra D, Steiner D, Lynch DH, Staiano-Coico L and Laurence J (1996) HIV-1 upregulates Fas ligand expression in CD4+ T cells in vitro and in vivo: association with Fas-mediated apoptosis and modulation by aurintricarboxylic acid. Immunol. 87: 581-585

100. Reed JC (1994) Bcl-2 and the regulation of programmed cell death. J. Cell. Biol. 124: $1-6$

101. Hu S, Vincenz C, Ni J, Gentz R and Dixit VM (1997) I-FLICE, a novel inhibitor of tumor necrosis factor receptor-1 and CD-95-induced apoptosis. J. Biol. Chem. 272: $17255-17257$

102. Inohara N, Koseki T, HuY, Chen Sand Nunez G (1997) CLARP, a death effector domain-containing protein interacts with caspase-8 and regulates apoptosis. Proc. Natl. Acad. Sci. USA 94: 10717-10722

103. Andre P, Groettrup M, Klenerman P, de Guilit R, Booth BL Jr, Cerundolo V, Bonneville M, JotereaultF, Zinkernagel RM and Lotteau V (1998) An inhibitor of HIV-1 protease modulates proteasome activity, antigen presentation, and T cell responses. Proc. Natl. Acad. Sci. USA 95: 13120-13124

104. Collier AC, Coombs RW, Schoenfeld DA, Bassett RL, Timpone J, Baruch A, Jones M, Facey K, Whitacre C, McAuliffe VJ, Friedman HM, Merigan TC, Reichman RC, Hooper C and Corey L. (1996) Treatment of human immunodeficiency virus infection with saquinavir, zidovudine, and zalcitabine. N. Engl. J. Med. 334: 1011-1017

105. Kaufmann D, Pantaleo G, Sudre P and Telenti A for the Swiss HIV Cohort Study. Research Letters. (1998) CD4-cell count in HIV-1-infected individuals remaining viraemic with highly active antriretroviral therapy (HAART). Lancet $351: 723-724$

106. Levitz SM (1998) Improvement in CD4+ cell counts despite persistently detectable HIV load. N. Engl. J. Med. 338: 1074-1075

107. Cohen J (1998) Failure isn't what it used to be ... but neither is success. Science 279: $1074-1134$

108. Carr A, Emery S, Kelleher A, Law M and Cooper DA (1996) CD8+ lymphocyte responses to antiretroviral therapy of HIV infection. J. Acquir. Immune Defic. Syndr. 13: $320-326$

109. Naito M, Nagashima K, Mashima T and Tsuruo T (1997) Phosphatidylserine externationization is a downstream event of interleukin- $1 \beta$-converting enzyme family protease activation during apoptosis. Blood 89: 2060-2066 